\title{
СОВЕРШЕНСТВОВАНИЕ ЗАКОНОДАТЕЛЬСТВА КАК НАПРАВЛЕНИЕ ПРЕДУПРЕЖДЕНИЯ ДОРОЖНО-ТРАНСПОРТНОЙ ПРЕСТУПНОСТИ
}

\author{
Баранчикова М.B.
}

Аннотация: Идея приоритета предупреждения диктует необходимость законодательного совершенствования деятельности по обеспечению безопасности дорожного движения и обязывает правоприменителей наряду с мерами ответственности шире использовать возможности предупредительного воздействия в данной сфере. Сегодня из общего количества дорожно-транспортных происшествий каждое третье является преступлением, а число последних за последние десятьлет возросло почти на $15 \%$. Такой рост количества дорожно-транспортных преступлений, увеличение числа и тяжести их последствий, является во многом следствием недостаточно оптимального законодательства в сфере обеспечения безопасности дорожного движения и требует улучшения состояния дорожно-транспортной безопасности. Эффективность предупреждения нарушений правил дорожного движения и эксплуатащии транспортных средств уголовно-правовыми методами зависит от умения применять положения законодательства в области обеспечения безопасности дорожного движения. Правовые меры, связанные с совершенствованием уголовного законодательства и прочих нормативных правовых актов, будучи основным направлением общих мер предупреждения преступных нарушений правил дорожного движения и эксплуатации транспортных средств, должны стать социально обусловленным средством улучшения дорожсной безопасности. Наряду с неотвратимым и справедливым наказанием виновных за преступления 8 сфере безопасности дорожного движения предупреждение преступлений в данной области общественной безопасности является опережсающим, перспективным и экономичным способом снижения дорожно-транспортного травматизма.

Ключевые слова: Предупреждения, дорожно-транспортная безопасность, движение, проистествие, преступность, правила, наказания, эксплуатаџия, санкиия, профилактика.

Важной тенденцией в деятельности современного российского государства выступает повышение эффективности предупреждения дорожно-транспортной преступности. При этом критическое состояние безопасности дорожного движения и эксплуатации транспортных средств обусловливает высокие требования к предупреждению дорожно-транспортных происшествий[1].

Идея приоритета предупреждения диктует необходимость законодательного совершенст- 
Так, В.И. Исаев справедливо отмечает, что

вования деятельности по обеспечению безопасности дорожного движения и обязывает правоприменителей наряду с мерами ответственности шире использовать возможности предупредительного воздействия в данной сфере.

Сегодня из общего количества дорожно-транспортных происшествий каждое третье является преступлением, а число последних за последние десять лет возросло почти на $15 \%$. Такой рост количества дорожно-транспортных преступлений, увеличение числа и тяжести их последствий, является во многом следствием недостаточно оптимального законодательства в сфере обеспечения безопасности дорожного движения и требует улучшения состояния дорожно-транспортной безопасности.

Эффективность предупреждения нарушений правил дорожного движения и эксплуатации транспортных средств уголовно-правовыми методами зависит от умения применять положения законодательства в области обеспечения безопасности дорожного движения.

В Федеральной целевой программы «Повышение безопасности дорожного движения в 2013 - 2020 годах» указано, что «обеспечение безопасности дорожного движения является составной частью задач обеспечения личной безопасности, решения демографических, социальных и экономических проблем, повышения качества жизни и содействия региональному развитию. В ряде стратегических и программных документов вопросы обеспечения безопасности дорожного движения определены в качестве приоритетов социально-экономического развития Российской Федерации [3].

Наличие уголовной ответственности за нарушение правил дорожного движения само по себе выступает важным профилактическим средством, применение которого во многом определяется состоянием законодательства в сфере дорожного движения, к которому нас отсылают бланкетные диспозиции норм уголовного закона. Совершенствование уголовного закона является важным направлением уголовной политики в сфере обеспечения безопасности дорожного движения, изменения которого влияют на общее состояние и последствия дорожно-транспортной аварийности [3]. «ст. 264 УК РФ в определенной степени оказывает предупредительное воздействие на потенциальных и действительных субъектов преступлений.. и требует усилить предупредительную функцию уголовного закона с одновременным изучением причин и условий совершения подобных правонарушений»[4].

В период с 2011 года по настоящее время на рассмотрении Государственной Думы Российской Федерации находился целый ряд законопроектов, направленных на усиление уголовной ответственности за дорожно-транспортные преступления. Предлагалось восстановить уголовную ответственность за нарушения правил дорожного движения и эксплуатации транспортных средств, повлекших средний тяжести сред здоровью при их совершении лицом, находящимся в состоянии опьянения, увеличить верхние пределы санкций по ч. 4 и ч. 6 ст. 264 УК РФ и т.д. Большинство из этих проектов были отклонены по причине наличия в административном законодательстве норм, предусматривающих ответственность за аналогичные деяния, достаточности мер административной ответственности за их совершение.

В то же время один из проектов, направленных на установление уголовной ответственности за управление транспортным средством лицом, находящимся в состоянии опьянения, был принят и одобрен. Так, Федеральным законом от 31 декабря 2014 г. № 528-Ф3 «О внесении изменений в отдельные законодательные акты Российской Федерации по вопросу усиления ответственности за совершение правонарушений в сфере безопасности дорожного движения» в уголовный закон включена ст. 264.1 «Нарушение правил дорожного движения лицом, подвергнутым административному наказанию», а также установлены нижние пределы санкций в виде лишения свободы по ч.4 и ч. 6 ст. 264 УК РФ.

Данным законом изменено примечание к ст. 264 УК РФ в части расширения смысла термина «другие механические транспортные средства», под которыми теперь понимаются трактора, самоходные дорожно-строительные и иные самоходные машины, а также транс- 
портные средства, на управление которыми в соответствии с законодательством Российской Федерации о безопасности дорожного движения предоставляется специальное право.

Анализ судебной практики свидетельствует о необходимости тщательного изучения действующего законодательства об автотранспортных преступлениях, разработки предложений по его совершенствованию [5].

Сегодня изменения уголовного закона, Правил дорожного движения Российской Федерации и других нормативных актов в сфере обеспечения безопасности дорожного движения продолжаются и требуют их своевременного учета в правоприменительной практике.

Необходима корректировка Постановления Пленума Верховного Суда РФ от 09.12.2008 г. № 25 «О судебной практике по делам о преступлениях, связанных с нарушением Правил дорожного движения и эксплуатации транспортных средств, а также с их неправомерным завладением без цели хищения» [7] в части приведения его в соответствие с изменениями в вышеуказанные нормативные правовые акты.

В современный период основное направление повышения эффективности предупреждения дорожно-транспортных преступлений видится как в постоянном совершенствовании дорожно-транспортных норм, направленном на их соответствие современным криминологическим реалиям, так и в обеспечении неотвратимости и справедливости ответственности за их нарушение. В условиях широкого распространения преступных нарушений правил дорожного движения и эксплуатации транспортных средств, постоянных изменений дорожно-транспортного законодательства, предупреждение начинает играть важную, определяющую роль.

Правовые меры, связанные с совершенствованием уголовного законодательства и прочих нормативных правовых актов, будучи основным направлением общих мер предупреждения преступных нарушений правил дорожного движения и эксплуатации транспортных средств, должны стать социально обусловленным средством улучшения дорожной безопасности. Наряду с неотвратимым и справедливым наказанием виновных за преступления в сфере безопасности дорожного движения предупреждение преступлений в данной области общественной безопасности является опережающим, перспективным и экономичным способом снижения дорожно-транспортного травматизма.

\section{Библиография:}

1. Бохан А.П., Иванов В.Д., Мясников В.В. Вопросы предупреждения нарушений правил дорожного движения и эксплуатации транспортных средств уголовно-правовыми методами // ЮристъПравоведъ. 2014. № 3 (64). С. 75-78.

2. Постановление Правительства РФ от 03.10.2013 № 864 «О федеральной целевой программе «Повышение безопасности дорожного движения в 2013-2020 годах» // Собрание законодательства РФ, 14.10.2013, № 41, ст. 5183.

3. Баранчикова М.В.Социальная обусловленность декриминализации нарушений правил дорожного движения // Наука и практика. 2015. № 1(62). С. 13.

4. Исаев Н.И. Уголовная ответственность за нарушение Правил дорожного движения и эксплуатации транспортных средств: научно-практическое пособие / Под ред. Н.Г. Кадникова. М.: Юриспруденция, 2011. С. 17.

5. Рудакова Г.И. Правовые аспекты безопасности дорожного движения // Вестник Адыгейского государственного университета. Серия 1: Регионоведение: философия, история, социология, юриспруденция, политология, культурология. 2013. № 1(113). С. 185. 
6. Постановление Пленума Верховного суда Российской Федерации от 9 декабря 2008 г. № 25 «О судебной практике по делам о преступлениях, связанных с нарушением правил дорожного движения и эксплуатации транспортных средств, а также с их неправомерным завладением без цели хищения» // Российская газета. 2008. № 265. 26 декабря.

\section{References (transliterated):}

1. Bokhan A.P., Ivanov V.D., Myasnikov V.V. Voprosy preduprezhdeniya narushenii pravil dorozhnogo dvizheniya i ekspluatatsii transportnykh sredstv ugolovno-pravovymi metodami // Yurist"'-Pravoved". 2014. № 3 (64). S. 75-78.

2. Postanovlenie Pravitel'stva RF ot 03.10 .2013 № 864 «O federal'noi tselevoi programme «Povyshenie bezopasnosti dorozhnogo dvizheniya v 2013-2020 godakh» // Sobranie zakonodatel'stva RF, 14.10.2013, № 41, st. 5183.

3. Baranchikova M.V.Sotsial'naya obuslovlennost' dekriminalizatsii narushenii pravil dorozhnogo dvizheniya // Nauka i praktika. 2015. № 1(62). S. 13.

4. Isaev N.I. Ugolovnaya otvetstvennost' za narushenie Pravil dorozhnogo dvizheniya i ekspluatatsii transportnykh sredstv: nauchno-prakticheskoe posobie / Pod red. N.G. Kadnikova. M.: Yurisprudentsiya, 2011. S. 17.

5. Rudakova G.I. Pravovye aspekty bezopasnosti dorozhnogo dvizheniya // Vestnik Adygeiskogo gosudarstvennogo universiteta. Seriya 1: Regionovedenie: filosofiya, istoriya, sotsiologiya, yurisprudentsiya, politologiya, kul’turologiya. 2013. № 1(113). S. 185.

6. Postanovlenie Plenuma Verkhovnogo suda Rossiiskoi Federatsii ot 9 dekabrya 2008 g. № 25 «O sudebnoi praktike po delam o prestupleniyakh, svyazannykh s narusheniem pravil dorozhnogo dvizheniya $\mathrm{i}$ ekspluatatsii transportnykh sredstv, a takzhe s ikh nepravomernym zavladeniem bez tseli khishcheniya» // Rossiiskaya gazeta. 2008. № 265. 26 dekabrya. 